\title{
Dual Effects of Angiotensin II on Calcium Currents in Neonatal Rat Nodose Neurons
}

\author{
K. Bacal and D. L. Kunze \\ Department of Molecular Physiology and Biophysics, Baylor College of Medicine, Houston, Texas 77030
}

\begin{abstract}
Angiotensin II (AII) reversibly modulates calcium current in isolated neonatal rat nodose ganglion cells by two different pathways. A maximum inhibitory effect of $43 \pm 6 \%(n=25)$ of the peak calcium current at $-10 \mathrm{mV}$ was observed at 10 $\mathrm{nM}$ All. The $\mathrm{IC}_{50}$ of the inhibitory response was $100 \mathrm{pM}$. Losartan, a specific antagonist for the AT, type of All receptor, abolished the All-induced inhibition, as did preincubation with pertussis toxin (PTX). When $\omega$-conotoxin GVIA (CTX) was added to the bath solution, All produced no inhibition of the remaining calcium current, indicating that the All inhibition was mediated through CTX-sensitive calcium channels. Reversible facilitation of calcium current was seen more rarely. The All-induced facilitation was unaffected by losartan and PTX, indicating that the effect is mediated by a non$A T$, receptor and does not depend upon a PTX-sensitive G-protein. The facilitation is present when the CTX-sensitive current has been blocked and involves activation of a reserve pool of dihydropyridine (DHP)-sensitive channels. In general, a particular neuron exhibited either inhibition or facilitation. However, in some neurons both inhibition and facilitation could be demonstrated in the presence of the appropriate blocking agents.
\end{abstract}

[Key words: calcium, baroreceptor, nodose, angiotensin II, w-conotoxin, losartan]

Angiotensin II (AII) is present in many regions of the brain, but levels are particularly high in cardiovascular control centers such as the nucleus of the tractus solitarius (NTS) (Fuxe et al., 1988). An immunohistochemical study has reported the presence of AII-containing terminals specifically in the medial division of the NTS (mNTS), the site of the first synapse of the baroreflex (Lind et al., 1985). Receptors for the peptide are also present in this area, as indicated by the finding that microinjection of AII into the mNTS provokes a dose-dependent change in blood pressure (Casto and Phillips, 1986) and by studies using radiolabeled AII and AII antagonists that reveal a high number of binding sites in the mNTS (Gutkind et al., 1988).

There is indirect evidence to suggest that at least a portion of the binding sites in the mNTS are located on the central terminals and/or axons of sensory afferent fibers. The number of AII binding sites in the medulla significantly decreases following ligation of the vagus or the sinoaortic depressor nerve (Diz et al., 1986;

\footnotetext{
Received Dec. 28, 1993; revised May 20, 1994; accepted May 26, 1994.

This work was supported by HL36840 to D.L.K. K.B. was supported by USPHST32-HL07676.

Correspondence should be addressed to Dr. D. L. Kunze, Department of Molecular Physiology and Biophysics, 1 Baylor Plaza, Houston, TX 77030.

Copyright (C) 1994 Society for Neuroscience $0270-6474 / 94 / 147159-09 \$ 05.00 / 0$
}

Speth et al., 1987). A. M. Allen et al. (1988) have demonstrated AII receptor binding in both neuronal cell bodies of the nodose ganglion and the fibers of the sensory nodose neurons. These studies suggest that AII receptors are located on presynaptic sensory terminals and that AII may exert its influence in the mNTS by presynaptic modulation of neurotransmitter release. The nodose ganglia contain the cell bodies of peripheral receptors of various sensory modalities, including the aortic baroreceptors, and as such provide us with access to the presynaptic cells of the first synapse of the reflex pathway. We chose to investigate the effects of AII on the whole-cell calcium currents because of the important role played by this presynaptic conductance in neurotransmitter release. The work was facilitated by recent characterization of calcium currents in the aortic baroreceptors (Mendelowitz and Kunze, 1992).

Preliminary reports have appeared earlier (Bacal et al., 1991; Bacal and Kunze, 1993).

\section{Materials and Methods}

Neonatal Sprague-Dawley rats $(1 \mathrm{~d}$ old $)$ of both sexes were sacrificed, and the nodose ganglia were excised and enzymatically digested in a solution containing Earle's Balanced Salt Solution with $5 \mathrm{mg} / \mathrm{ml}$ trypsin (Worthington Biochemical), $12 \mathrm{~mm}$ cysteine, $0.5 \mathrm{~mm}$ EDTA, and 1.5 $\mathrm{mm} \mathrm{CaCl}$.

After a $30 \mathrm{~min}$ digestion at $37^{\circ} \mathrm{C}$, cells were mechanically dispersed and plated onto poly-D-lysine-coated coverslips at an approximate density of 100,000 cells/dish. Cells were maintained in nodose complete media [Dulbecco's Modified Eagle Medium with 5\% fetal bovine serum (JRH Biosciences), $0.1 \%$ serum extender (MITO, Collaborative Research), $1 \%$ penicillin/streptomycin, and $8 \mathrm{ng} / \mathrm{ml}$ nerve growth factor (CR 7S, Collaborative Research)] at $37^{\circ} \mathrm{C}$ and $5 \% \mathrm{CO}_{2}$ for $15-48 \mathrm{hr}$ before use. At this time, cell bodies were spherical (diameter $\sim 20-30$ $\mu \mathrm{m})$, with minimal processes.

To isolate the calcium currents in these cells, the bath solution consisted of (in mM) 139 tetraethylammonium chloride, $2 \mathrm{CaCl}_{2}, 2$ glucose, 10 hydroxyethylpiperazine- $N$-2-ethane sulfonic acid (HEPES), and 5 4-aminopyridine, $\mathrm{pH}$ 7.4. The intracellular pipette solution contained (in mM) $124 \mathrm{CsCl}$ and $10 \mathrm{HEPES}$ with free calcium buffered to approximately $100 \mathrm{nM}$ by $11 \mathrm{EGTA}, 1 \mathrm{CaCl}_{2}$, and $2 \mathrm{MgCl}_{2}, \mathrm{pH} 7.2$.

For most experiments, the perforated patch technique using $50 \mu \mathrm{g} /$ $\mathrm{ml}$ nystatin added to the pipette solution was used to prevent washout of the cell interior. Cell-attached patches were made on the nodose cell bodies using polished electrodes pulled from 8161- or 7052-type glass (Garner Glass). Tip resistances were 1-3 M 2 and junction potentials were $1-3 \mathrm{mV}$. Access to the intracellular compartment was indicated by a change in capacitative transients and input resistance (usually 5$20 \mathrm{~min}$ ). When whole-cell open patches were used, nystatin was omitted from the intracellular solution.

All experiments were carried out at room temperature. The indifferent electrode was a silver-silver chloride plug connected to the bath solution via a $150 \mathrm{~mm}$ potassium chloride bridge. Calcium current recordings were obtained during constant perfusion with either bath or experimental solutions from a large-bore multibarrel pipette positioned close to the cell.

Angiotensin II was obtained from Bachem. $\omega$-conotoxin GVIA (CTX) 


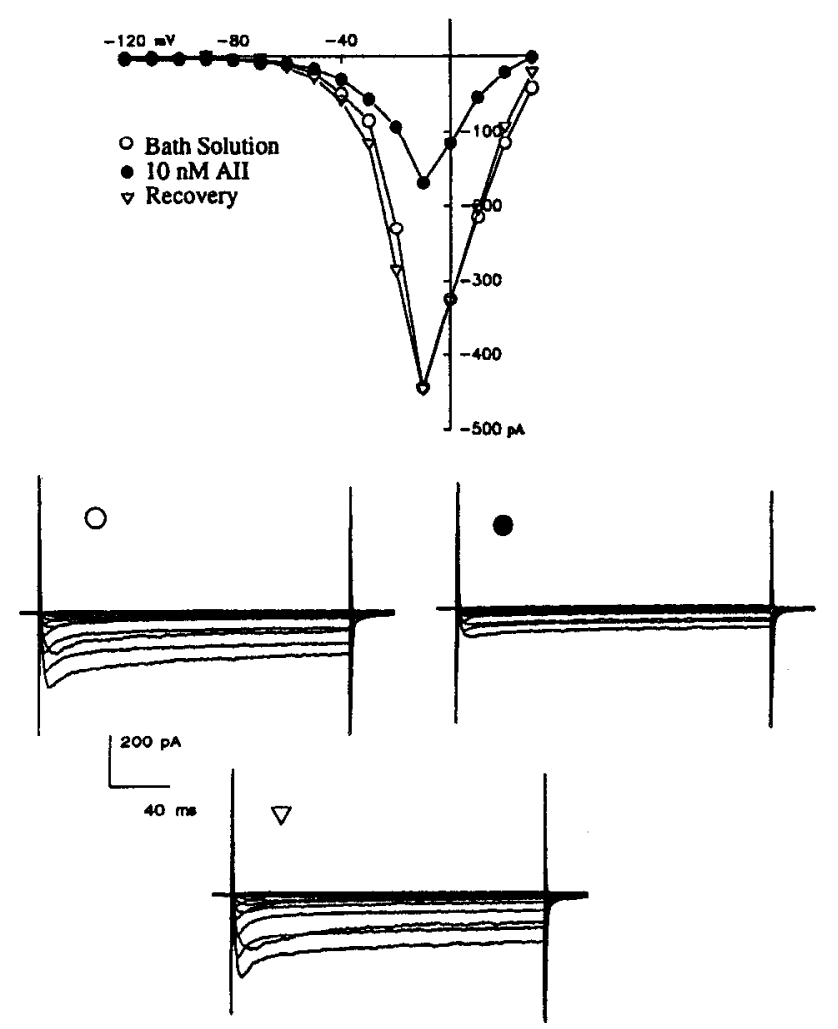

Figure 1. Current traces and resulting current-voltage relationship demonstrating the reversible effect of $10 \mathrm{~nm}$ AII on whole-cell calcium current in an individual neuron. The pulse protocol stepped from -120 $\mathrm{mV}$ to $+30 \mathrm{mV}$ for $300 \mathrm{msec}$ in intervals of $+10 \mathrm{mV}$.

was purchased from Sigma Chemical, while nimodipine and Bay $\mathrm{K}$ 8644 [2,6-dimethyl-3-carbomethoxy-5-nitro-4-(2-trifluoromethylphenyl)-1,4-dihydropyridine; "Bay K"] were kindly provided by Dr. A. Scriabne, Miles Laboratories, Inc. (West Haven, CT). Losartan [DuP753; 2-butyl-4-chloro-1-[(2'-(1H-tetrazol-5-yl)biphenyl-4-l)-methyl]5 -(hydroxymethyl)imidazol] was kindly provided by the DuPont Merck Pharmaceutical Company (Wilmington, DE); CGP 42112B [nicotinylTyr-( $N$-benzyl-oxycarbonyl-Arg)-Lys-His-Pro-Ile-OH], by Dr. M. de Gasparo, CIBA-GEIGY, Switzerland; and PD 123319 (1-[4-(dimethylamino)-3-methylphenyl]-5-(diphenylacetyl-4,5,6,7-tetrahydro-1H-imidazo[4,5-c]pyridine-6-carboxylic acid), by Dr. J. Keiser (Research Division, Parke-Davis Pharmaceutical Company, Ann Arbor, MI).

Voltage protocols were applied, and currents measured, with pCLAMP software (Axon Instruments). Data were acquired using the CLAMPEX program and analyzed with CLAMPAN and/or CLAMPFIT. A normalization procedure was necessary for grouped data because the amplitude of the calcium current varied considerably from cell to cell. In some figures the currents are therefore expressed as percentages of the maximum current.

\section{Results}

The effect of AII on the calcium currents of individual neurons was one of three types: solely inhibitory, solely facilitory, or a mixed facilitation-inhibition. All neurons cultured from animals of the same litter behaved similarly. The data are presented below for each of the two individual effects and then for cells in which the dual effect was observed.

\section{Inhibitory effects of $A I I$}

The effects of 10 and $100 \mathrm{~nm}$ AII on calcium current were studied using the perforated patch technique to reduce the washout of second messenger substances. In this set of experiments the voltage of the neuron was routinely clamped at a holding po-

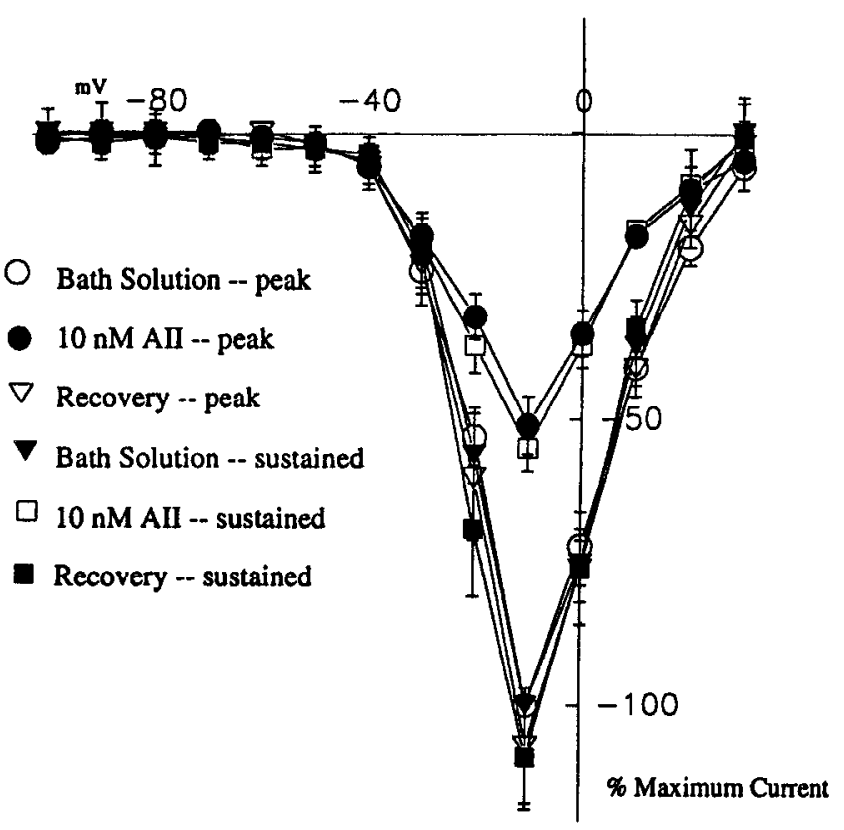

Figure 2. The effect of AII on the peak and steady-state (at 275-295 msec) calcium current $(n=12)$ utilizing protocol described in Figure 1. Current was normalized to peak valuc (at $10 \mathrm{mV}$ ).

tential of $-80 \mathrm{mV}$. A pulse protocol consisting of steps in 10 $\mathrm{mV}$ increments from -120 to $+30 \mathrm{mV}$ was applied to obtain a current-voltage relationship. In the control records, a lowthreshold "T-type" current of modest magnitude was observed in approximately half the cells studied. This current can be seen in the current-voltage relationship (Fig. 1) as the small current present at -60 to $-40 \mathrm{mV}$. Even at maximum amplitude, the T-type current was less than $10 \%$ of the maximum amplitude of the high-threshold current observed at $-10 \mathrm{mV}$. The highthreshold current was activated at potentials more positive than $-40 \mathrm{mV}$ and at least two kinetic components were evident during a 300 msec voltage step: a transient current that quickly inactivates and a longer lasting current that persists through the end of the voltage pulse (for detailed description, see Mendelowitz and Kunze, 1993).

As can be seen in Figure 1, $10 \mathrm{~nm}$ AII caused a net reduction in the current elicited at all voltages positive to $-40 \mathrm{mV}$, voltages that activate the high-threshold calcium currents. AII at $10 \mathrm{nM}(n=25)$ or $100 \mathrm{nM}(n=14$; not shown) induced a net inhibition of the calcium current of $43 \pm 4 \%$ and $40 \pm 6 \%$, respectively, at the peak current. The AII effect was reversible within a few seconds of reperfusion with bath solution.

To ascertain whether AII acts preferentially on the transient or the steady-state component of the high-threshold current, the current in 12 cells was measured at both peak current and at the end of the step (275-295 msec). No difference was found between the maximum and sustained current responses to 10 nM AII (Fig. 2).

While these results clearly indicated the inhibitory effect of AII on the high-threshold currents, an effect of the peptide on the low-threshold currents was not apparent. Because of overlap in the high-threshold and the low-threshold "T-type" currentvoltage relationships and the small amplitude of the T-type current when present, an AII effect on the T-type current cannot be completely ruled out. However, examination of the grouped current-voltage relationships in the presence and absence of AII 


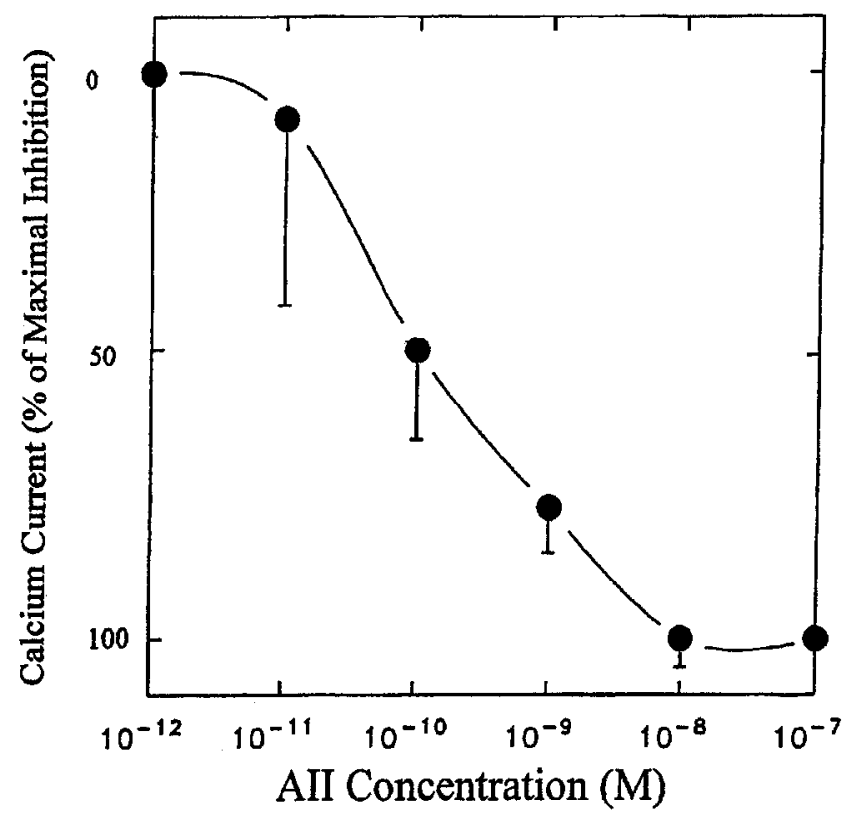

Figure 3. Concentration-response curve for AII inhibition. Calcium current of each cell was normalized to the maximum current remaining with a step to $-10 \mathrm{mV}$ during perfusion with $10 \mathrm{~nm}$ AII. Data were averaged for each point and fit by a single site binding model $(R=$ $0.97) . n=3$ at $1 \mathrm{pM}, 6$ at $10 \mathrm{pM}, 5$ at $100 \mathrm{pM}, 4$ at $1 \mathrm{nM}, 7$ at $10 \mathrm{nM}$, and 4 at $100 \mathrm{nM}$. Nimodipine ( $2 \mu \mathrm{M})$ was present in the bath to block any facilitatory response.

(Fig. 2) suggests that there is no effect on the low-threshold current.

Threshold for inhibition occurs between 1 and $10 \mathrm{pm}(n=3$, $n=6$, respectively) AII and reaches a maximum at $10 \mathrm{~nm}(n=$ 7). The data were fit by a single site binding curve to give an $\mathrm{IC}_{50}$ of $100 \mathrm{pm}$ (Fig. 3).

The effect of AII on voltage-dependent inactivation of the calcium current was also examined. Cells were exposed to a conditioning voltage for $2 \mathrm{sec}$, and then a test voltage step to 0 $\mathrm{mV}$ for $300 \mathrm{msec}$. Conditioning voltages were varied between -120 and $0 \mathrm{mV}$, and the results are displayed in Figure 4, which shows both individual and grouped responses. AII had no effect on the voltage-dependent inactivation of calcium current $(n=$ 7).

Effect of losartan on the AII-induced inhibition. Losartan, previously known as DuP 753 , is a specific antagonist for the $\mathrm{AT}_{1}$ subpopulation of AII receptors. Losartan (100 nM) alone had no effect on whole-cell calcium current.

The effect of $100 \mathrm{~nm}$ losartan when applied simultaneously with $10 \mathrm{~nm}$ AII was compared to the effect when $10 \mathrm{~nm}$ AII was perfused alone. In these cells, losartan completely reversed the inhibition produced by AII $(n=10$; Fig. 5$)$. This indicates that an $\mathrm{AT}_{1}$ receptor underlies the inhibition of calcium current.

Effect of GTP $\gamma$ s on the AII-induced inhibition. $\mathrm{AT}_{1}$ receptors in other systems have been shown to be coupled to G-proteins. To determine whether this was also the case for the nodose cells, GTP $\gamma$ s, an hydrolysis-resistant GTP analog, was employed. GTP $\gamma \mathrm{s}$ was added at $10 \mu \mathrm{M}$ to the intracellular solution, and an open patch whole-cell recording was obtained. When $10 \mathrm{~nm}$ AII was applied to this system, an irreversible net inhibition of calcium current ( $47 \pm 8 \% ; n=6$; Fig. 6$)$ was observed.

The decrease in calcium current is seen immediately (seconds) after application of AII in contrast to the time course of inhi-
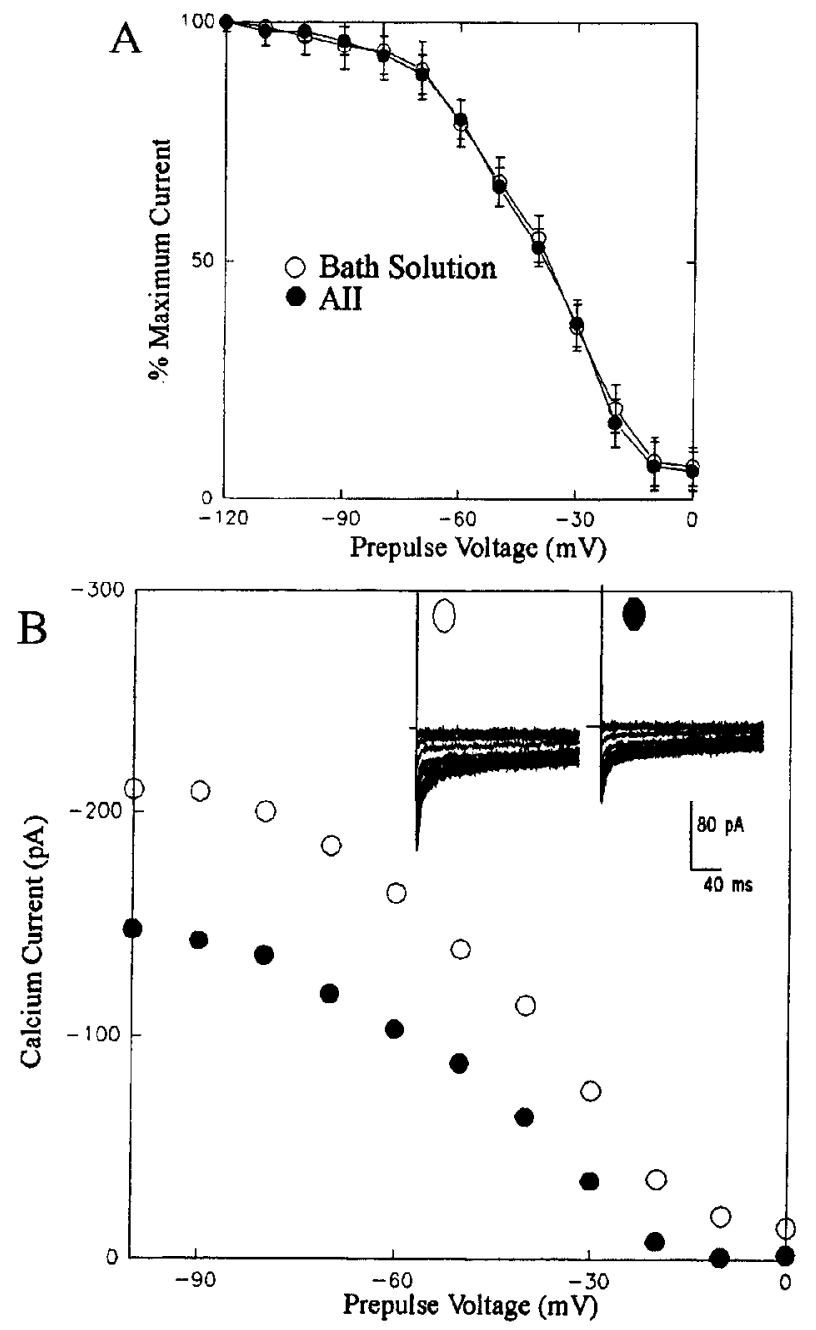

Figure 4. A, Effect of AII on the voltage dependence of inactivation of whole-cell calcium current in neurons demonstrating AII-induced inhibition. Cells were clamped at $-100 \mathrm{mV}$ and subjected to a $2 \mathrm{sec}$ prepulse before stepping to the test voltage of $0 \mathrm{mV}$. The prepulse was varied from -120 to $0 \mathrm{mV}$ increasing $10 \mathrm{mV}$ every $8 \mathrm{sec}$. Currents were normalized to the peak current seen following a prepulse to -120 $\mathrm{mV}$ to show superimposition of voltage dependence; data were then averaged $(n=7)$. $B$, Current traces and inactivation curve showing effect of AII on magnitude of the current in an individual neuron.

bition (several minutes) seen when GTP $\gamma$ s alone is added to the intracellular solution (Dolphin and Scott, 1989).

Effect of pertussis toxin on the AII-induced inhibition. As the GTP $\gamma$ s results indicated that a G-protein was involved in the AII-induced inhibition, a group of nodose cells was incubated overnight in media containing pertussis toxin $(200 \mathrm{ng} / \mathrm{ml})$, while another group (obtained from the same preparation) was incubated in control media. The control cells demonstrated the typical AII-induced net inhibition (data not shown; $41 \pm 5 \%$; $n=12$ ) of calcium current. In the pretreated cells, however, 10 nм AII had no significant effect on calcium current (Fig. 7; $n=$ 10 ), suggesting that a pertussis-sensitive G-protein is involved in AII-induced inhibition.

Effect of w-conotoxin on the AII-induced inhibition. As described previously by Mendelowitz and Kunze (1992), the majority of the high-threshold current $(65 \%)$, both transient and sustained components, was inhibited by $1 \mu \mathrm{M} \omega$-conotoxin GVIA. Although most of this current is inhibited quickly $(<5 \mathrm{~min})$, 


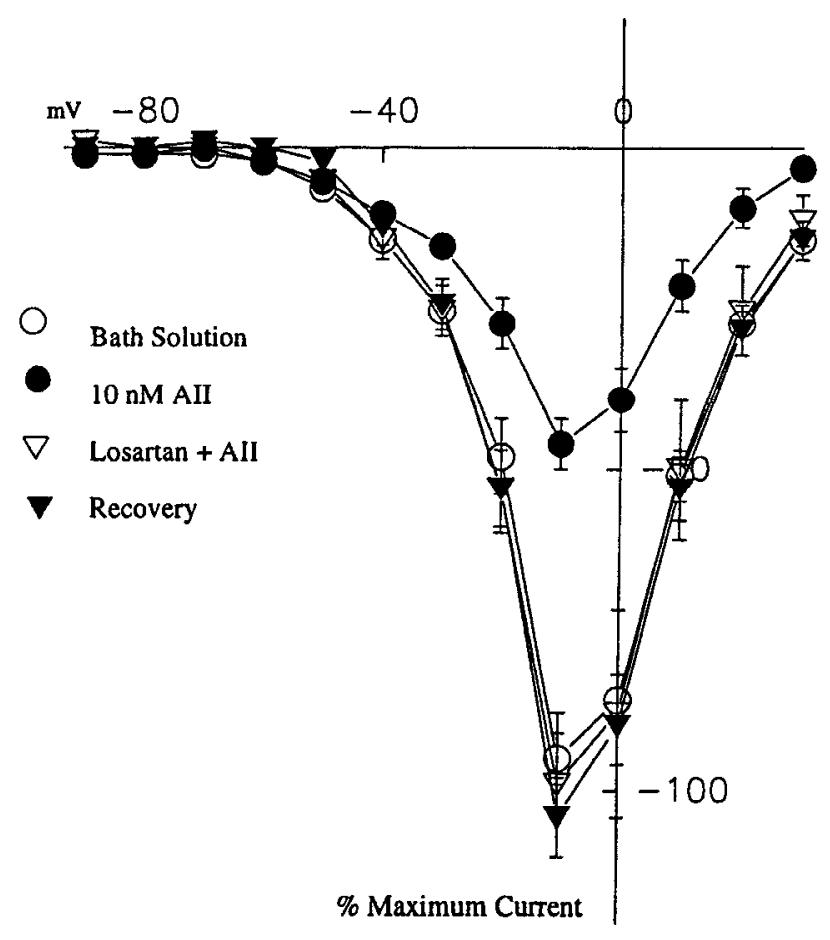

Figure 5. The effect of the $\mathrm{AT}_{1}$ receptor antagonist losartan on AIIinduced inhibition. Coperfusion of $100 \mathrm{~nm}$ losartan and $10 \mathrm{~nm}$ AII wholly abolished the inhibition of calcium current observed during perfusion of $10 \mathrm{nM}$ AII alone $(n=10)$.

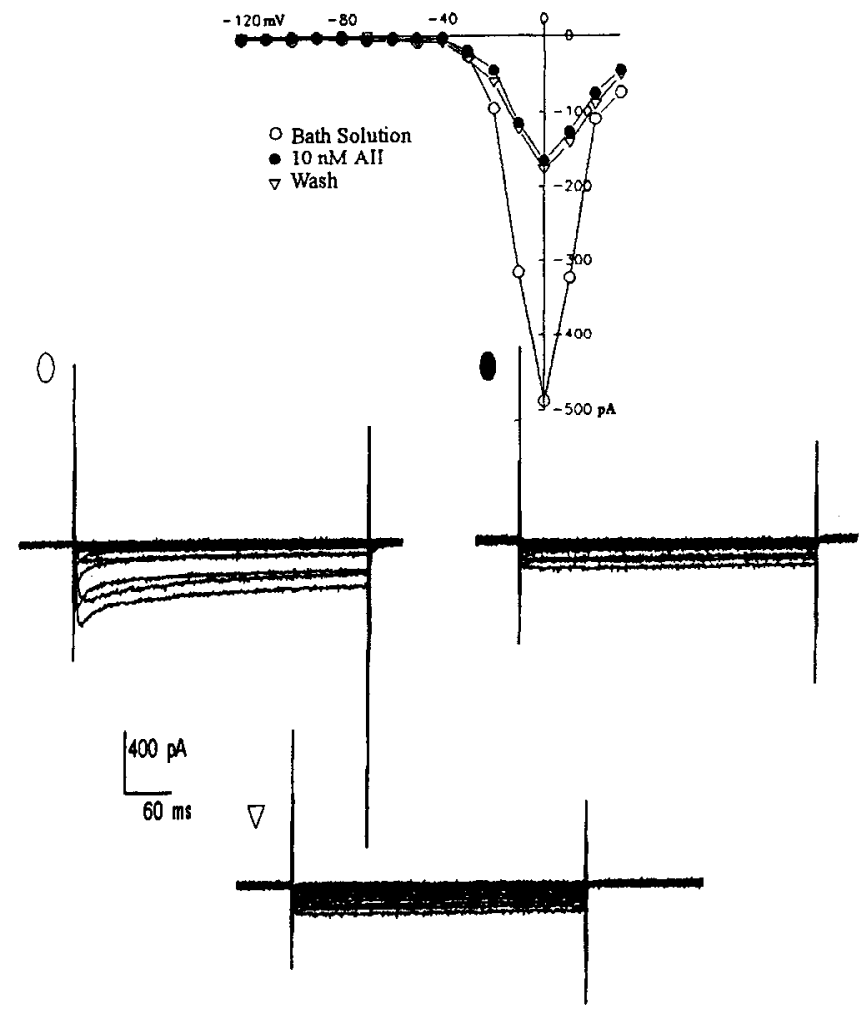

Figure 6. The effect of GTP $\gamma \mathrm{S}$ on AII-induced inhibition. In these experiments, nystatin was omitted from the intracellular solution, 100 $\mu \mathrm{M}$ GTP $\gamma \mathrm{s}$ was added, and open patch recordings were obtained. Current traces and the current-voltage relationship of a representative cell are shown.
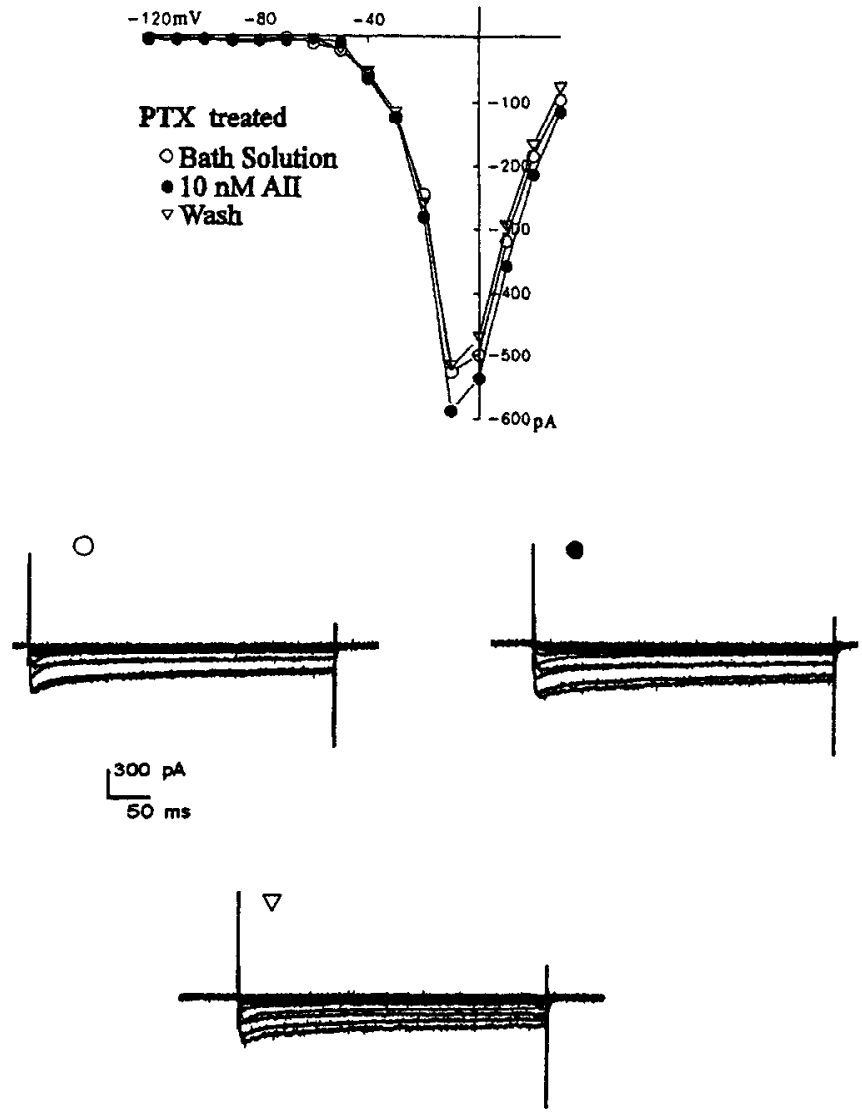

Figure 7. The effect of pertussis toxin $(P T X)$ on AII-induced inhibilion. A representative example from a group of nodose cells $(n=10)$ was incubated overnight in media containing PTX $(200 \mathrm{ng} / \mathrm{ml})$ while another group (obtained from the same preparation) was incubated in control media.

block increases progressively until a stable plateau is reached approximately $15 \mathrm{~min}$ after CTX application. In order to ensure that the observed decreases in calcium currents were the result of AII application and not further CTX block, cells were incubated for 15-45 min in $1 \mu \mathrm{M}$ CTX before study. As expected, a CTX-resistant current was present when the recording was obtained; this current was unaffected by application of AII ( $n$ =6; Fig. 8), while matched controls demonstrated an AII-induced inhibition of calcium current (data not shown; $44 \pm 7 \%$; $n-6)$. CTX-sensitive channels thus appear to underlie the AIIinduced inhibition.

\section{Facilitory effects of $A I I$}

Recordings were also obtained from neurons of litters in which the effect of AII was a reversible enhancement of the whole-cell calcium current. The amplitude of the facilitation was highly variable although it was similar among all neurons from the same litter. The composite current-voltage relationship for 10 of these cells is presented in Figure 9. In this set of cells the current increased by $76 \pm 11 \%$ of the peak control current elicited by a step to $-10 \mathrm{mV}$ (Fig. 9). Like inhibition, the facilitation was reversible. The high-threshold current was clearly increased; however, no facilitation of the T-type current was apparent.

The voltage dependence of inactivation was examined in one group of cells that demonstrated facilitation $(n=4)$. As can be seen by the comparison of the inactivation curves in the presence 


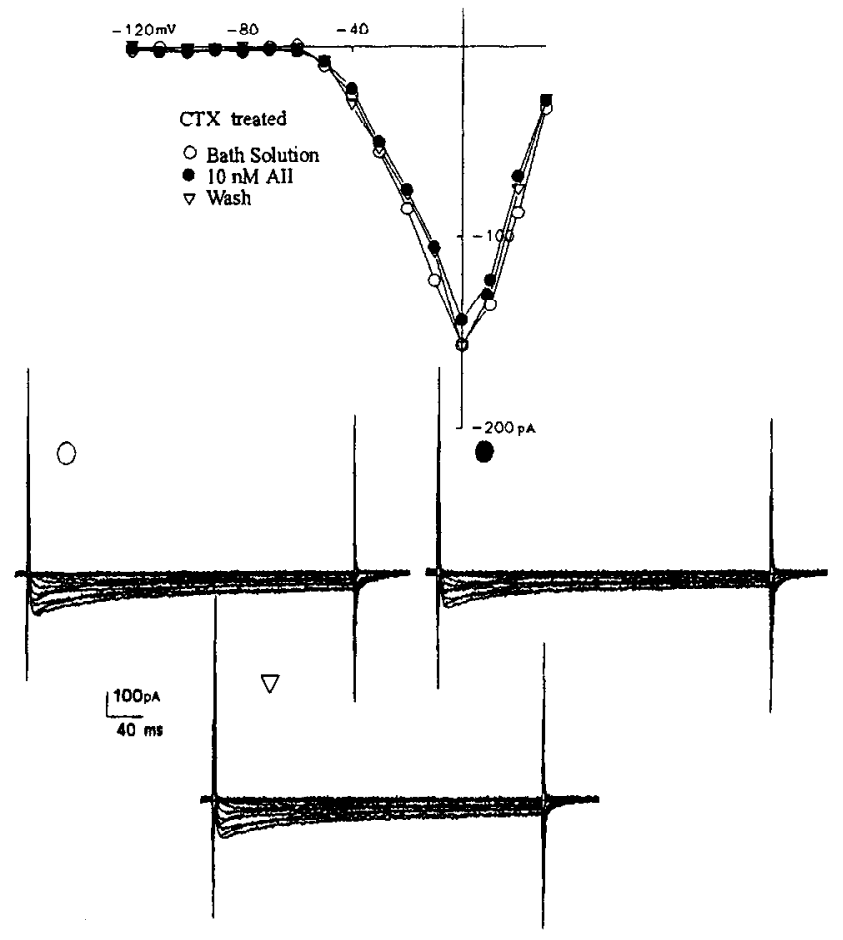

Figure 8. Current-voltage relationship and representative traces from a neuron following incubation in $1 \mu \mathrm{m} \mathrm{CTX}$; the CTX-resistant current was unaffected by AII $(n=6)$.

and absence of AII (Fig. 10), AII produced no significant change in the voltage dependence of inactivation.

Effect of losartan on the AII-induced facilitation. Unlike inhibition, facilitation of calcium current by AII was not affected by coperfusion with $100 \mathrm{~nm}$ losartan $(n=4)$, as demonstrated in Figure 11. Reperfusion with bath solution, however, caused current to return to baseline levels. In an attempt to determine whether the $\mathrm{AT}_{2}$ receptor type was responsible for the AIIinduced facilitation, both CGP 42112B and PD 123319 were employed. However, even at concentrations below $50 \mathrm{nM}$, these compounds displayed agonist activity on nodose calcium currents when perfused alone.

Effect of pertussis toxin on the AII-induced facilitation. Nodose cells were divided into pertussis and control groups as described above. The control cells $(n=6)$ responded to AII with a $21 \%( \pm 2 \%)$ increase in calcium current (data not shown). Pertussis pretreatment did not alter this effect (Fig. 12; $27 \pm$ $4 \% ; n=6$ ), thus indicating that a pertussis toxin-sensitive G-protein is not associated with the AII-induced facilitation.

Facilitation occurs in the presence of $C T X$. In four preparations, $10 \mathrm{nM}$ AII was applied after exposure of the cells to $1 \mu \mathrm{M}$ CTX for 15-30 min. In these cells the AII produced facilitation as illustrated in Figure 13, demonstrating that CTX-sensitive channels were not essential for the facilitory effect on calcium current.

DHP-sensitive channels and the AII-induced facilitation. Previous work had demonstrated, and we confirmed, that $2 \mu \mathrm{M}$ nimodipine, a dihydropyridine (DHP) antagonist, had little or no effect on calcium current in nodose cells (Mendelowitz and Kunze, 1993). However, application of $1 \mu$ M Bay K 8644, a DHP agonist, caused an increase in whole-cell calcium current ( $n=6$ of 6 ; Fig. 14) that was abolished by $2 \mu \mathrm{M}$ nimodipine (not shown). To determine whether AII may recruit the ni-

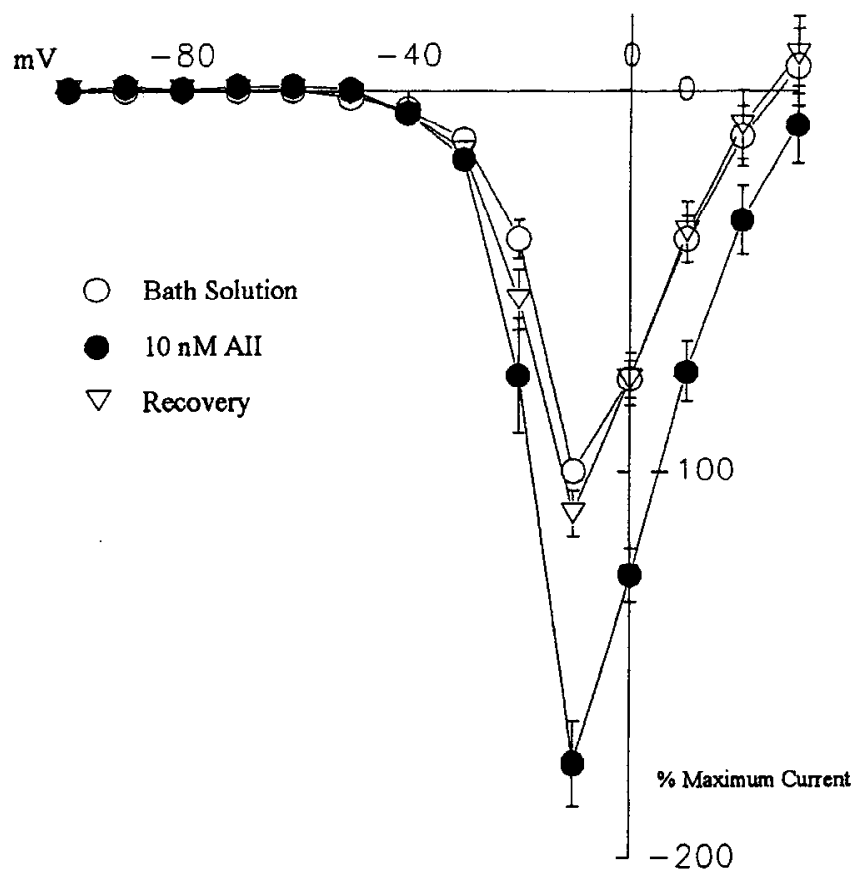

Figure 9. Current-voltage relationship demonstrating the magnitude and reversibility of AII-induced facilitation of calcium current $(n=10)$. Currents were normalized to the peak current $(-10 \mathrm{mV})$ during control conditions.

modipine-inhibitable, Bay K 8644-activatable pool of channcls, a current-voltage relationship in the presence of AII was obtained. Following recovery, Bay K 8644 was added to the perfusate and calcium current increased. When AII was added again, this time in the presence of Bay $\mathrm{K}$, there was no additional increase in the current ( $n=2$; Fig. 14), suggesting that Bay $\mathrm{K}$ and AII activate the same pool of channels.

Mixed responses to AII. Further support for the involvement of DHP-sensitive channels came from studies of neurons in which a dual response was present. As shown in Figure 15, perfusion of nimodipine had no effect on the baseline calcium current, and AII alone caused a small increase in calcium current $(12 \pm 2 \% ; n=4)$. However, when AII and nimodipine were perfused together, a reduction $(57 \pm 5 \%)$ in calcium current became apparent. In these neurons, the two mechanisms modulating calcium channel activity had been activated by the peptide and, being of nearly equal magnitude, had produced only a small activation. Once the facilitation pathway was blocked by nimodipine, however, the underlying inhibitory effect was unmasked. This response would be expected if the facilitation was mediated through DHP-sensitive channels.

\section{Discussion}

AII affects activity of a wide variety of cell types including vascular smooth muscle, cardiomyocytes, adrenal glomerulosa, astrocytes, and neurons (I. S. Allen et al., 1988; Iredale et al., 1992; McMillian et al., 1992; Pinzani et al., 1992; Saito et al., 1992; Tremblay et al., 1992). Most of the known systemic physiological responses to $\mathrm{AII}$ are mediated through the $\mathrm{AT}_{1}$ receptor via signal transduction pathways involving activation of phosphoinositide hydrolysis or inhibition of adenylate cyclase activity. The physiological functions of $\mathrm{AT}_{2}$ receptor activation, on the other hand, are for the most part unknown (Inagami and Harris, 1993; Timmermans et al., 1993). 

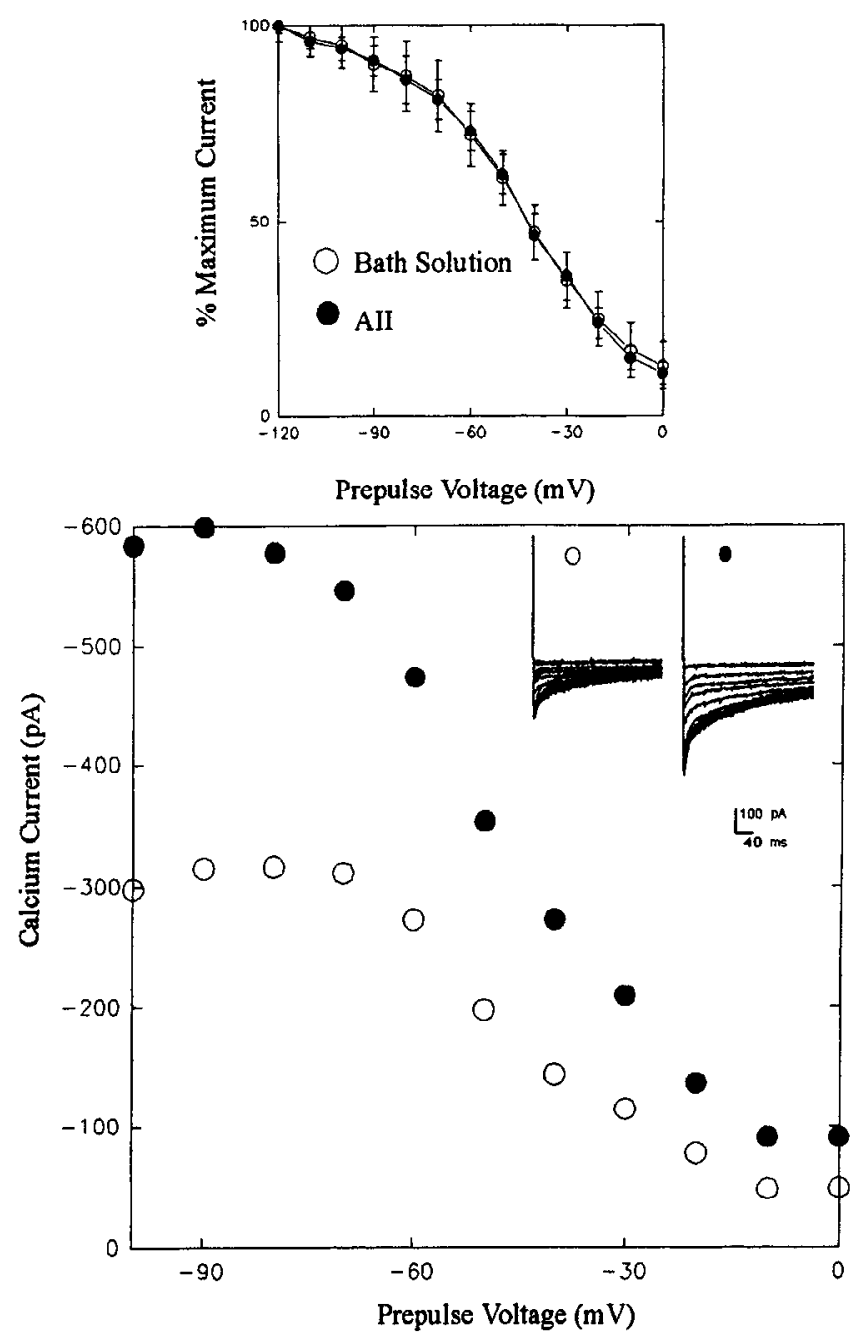

Figure 10. Top, Effect of AII on the voltage dependence of inactivation of whole-cell calcium current in neurons demonstrating AII-induced facilitation. Protocol is same as Figure 4. Currents were normalized to the peak current during the test pulse following a prepulse to $-120 \mathrm{mV}$. Bottom, Current traces and inactivation curve showing effect of AII in an individual neuron.

Direct evidence for AII effects on calcium channels has been obtained in cardiac myocytes, adrenal glomerulosa cells, adrenal medullary chromaffin cells, neurons, and vascular smooth muscle. These effects have been excitatory and are discussed below.

\section{AII-induced inhibition}

The concentration-response curve for AII-induced inhibition of calcium current is consistent with binding studies for the $\mathrm{AT}_{1}$ receptor by Healy et al. (1989). Block of the AII-induced inhibition by losartan confirms the role of the $\mathrm{AT}_{1}$ receptor. This receptor is widely accepted to be a member of the G-protein receptor family, a notion that is supported by the present findings using GTP $\gamma$ s and pertussis toxin. Of the calcium currents thus far identified in nodose neurons, the inhibition appeared to be restricted to the CTX-sensitive channel.

Many other neuromodulators also inhibit neuronal calcium currents through PTX-sensitive G-proteins (Hescheler et al., 1987; Dolphin and Scott, 1989; Crain and Shen, 1990; Wiley et al., 1990) and several inhibitors have been shown to act specifically on CTX-sensitive channels (Cox and Dunlap, 1992;
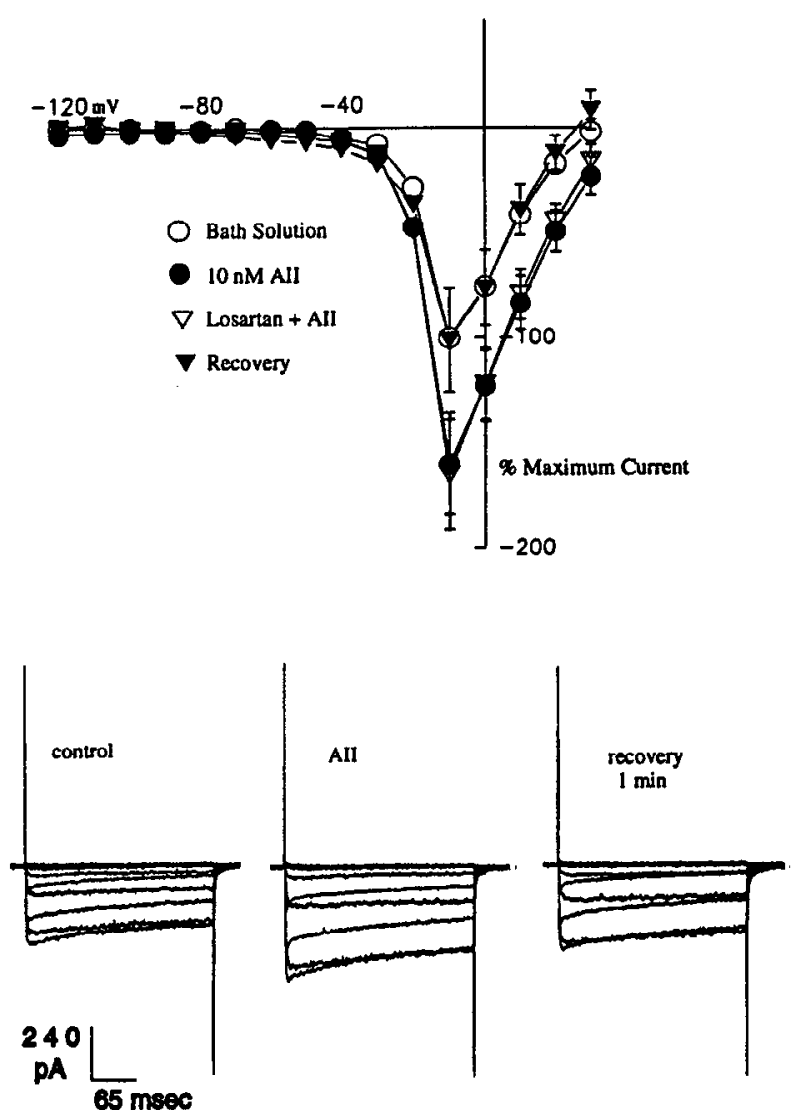

Figure 11. Current-voltage relationship and representative current traces are compared for control and AII in the absence and presence of the $\mathrm{AT}_{1}$ receptor antagonist losartan $(n=4)$. The pulse protocol, 300 msec voltage steps from $-120 \mathrm{mV}$ to $+30 \mathrm{mV}$, was delivered $1 / 3 \mathrm{sec}$.

Mogul et al., 1993; Yawo and Chuhma, 1993), as in the present study. Thus, the AII-induced inhibition of nodose cell calcium current appears to be a member of a large family of similar systems.

\section{AII-induced facilitation}

AII-induced facilitation was seen with less frequency than inhibition. It is clear that the losartan-sensitive $\mathrm{AT}_{1}$ receptor is not involved in the facilitation, but further identification could not be confirmed due to the partial agonist effects of the two $\mathrm{AT}_{2}$-specific antagonists. Chaki and Inagami (1992) have recently identified an AII receptor in a neuroblastoma cell line that is not blocked by $\mathrm{AT}_{1}$ or $\mathrm{AT}_{2}$ antagonists. Thus, the possible alternatives to the $\mathrm{AT}_{1}$ receptor are not limited to $\mathrm{AT}_{2}$ receptors.

The reported effects of AII on calcium channels have been excitatory and not uniformly on the same channel type. In frog atrial myocytes the low-threshold calcium current is increased while a DHP-sensitive high-threshold current is unaffected (Bonvallet and Rougier, 1989). Cohen et al. (1988) also report an increase in low-threshold calcium current in adrenal glomerulosa cells. In contrast, in neonatal rat cardiac myocytes and in portal vein smooth muscle the high-threshold DHP-sensitive current is stimulated by AII (I. S. Allen et al., 1988). In the present study the DHP-sensitive calcium channel was shown to underlie an AII-induced facilitation and an effect on low threshold channels was not evident. However, this latter current is absent in approximately $50 \%$ of the cells, is very small in the 


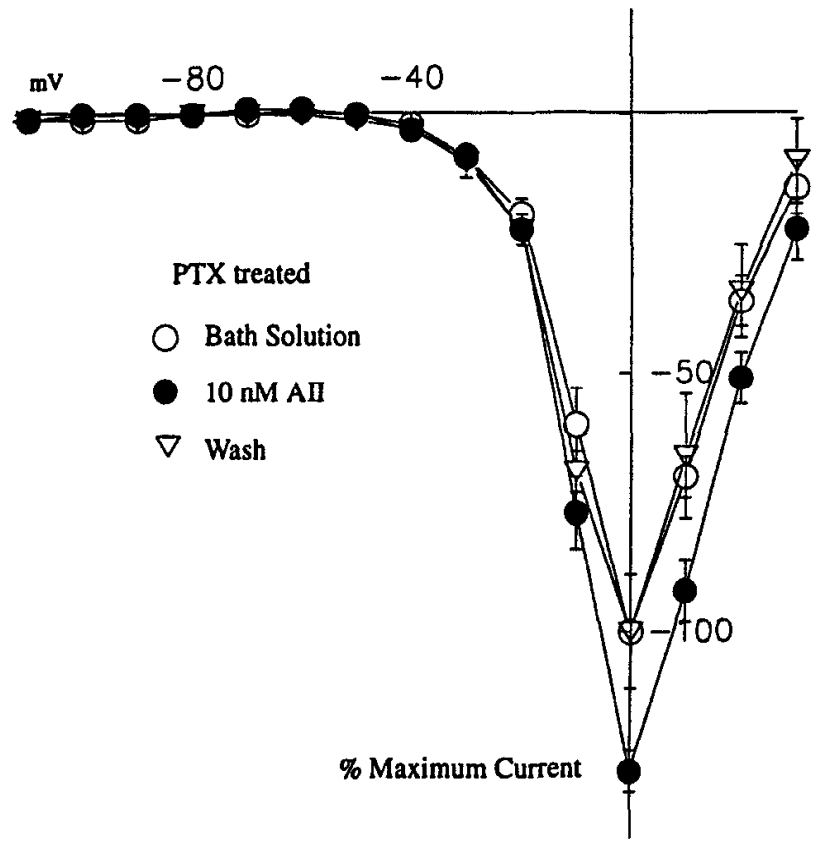

Figure 12. The effect of overnight incubation with pertussis toxin $(200$ $\mathrm{ng} / \mathrm{ml}$ ) on AII-induced facilitation. The control cells responded to AII with a $21 \%$ increase in calcium current (not shown). PTX did not alter the facilitation $(27 \% ; n=6)$.

remainder, and therefore is difficult to evaluate. The activation of calcium current by AII in the nodose neurons resembles that in cardiac myocytes where both the early and late components of DHP current are stimulated (I. S. Allen et al., 1988). In further comparisons, the myocyte study showed only a very small shift $(+2.6 \mathrm{mV})$ in the inactivation curve with AII; our study was similar, with no change in voltage dependence of inactivation.

The DHP-sensitive channel is well characterized in other neuronal systems and has been reported to exist in a "reserve pool"

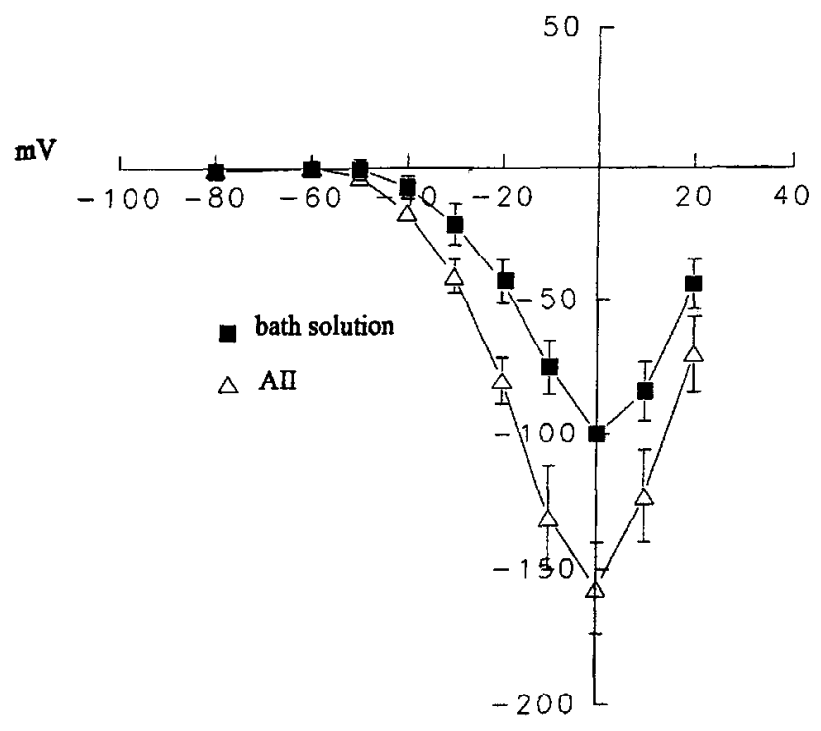

\section{$\%$ maximum current}

Figure 13. Current-voltage relationship in the presence and absence of $10 \mathrm{nM}$ AII for cells that had been incubated in $1 \mu \mathrm{M}$ CTX for 15-30 $\min (n=4)$.

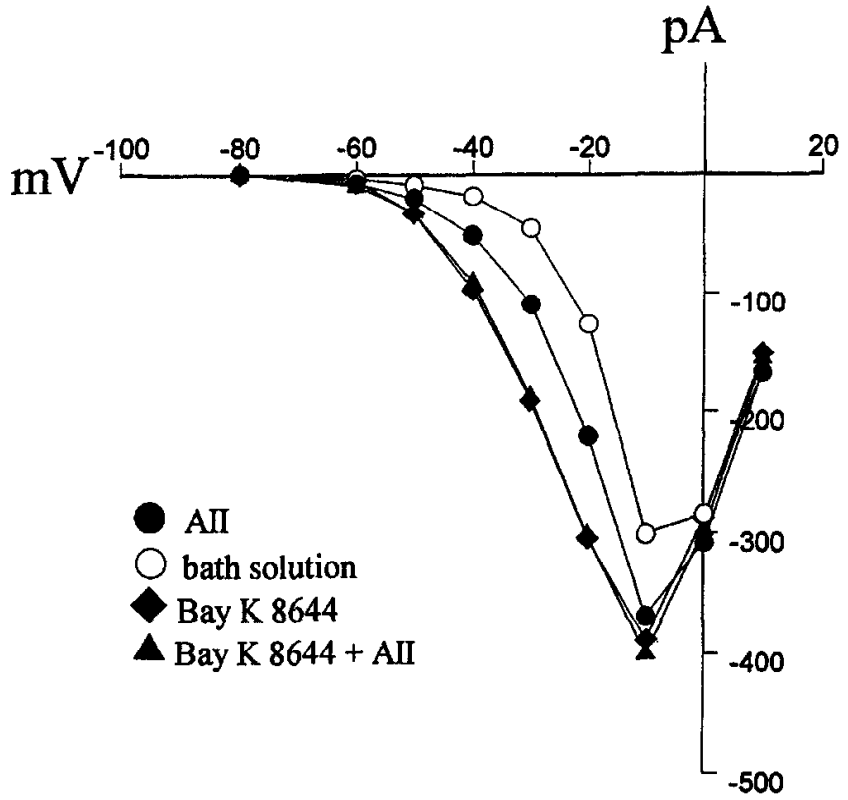

Figure 14. Current-voltage relationships of a representative neuron $(n=2)$ showing the lack of effect of AII $(10 \mathrm{nM})$ in the presence of 1 $\mu \mathrm{M}$ Bay K 8644 . The pulse protocol described in Figure 11 was used to activate calcium current in the following sequence: in the presence of AII ( $(\bullet)$, after removal of AII (O), upon subsequent addition of Bay $K$ $(\triangleleft)$, followed by Bay K and AII ( $\boldsymbol{\Lambda})$.

(Artalejo et al., 1990), as is proposed in this study. When activated by Bay K 8644 or AII (or perhaps other factors as well), these reserve channels can then contribute markedly to the wholecell calcium current.

\section{Dual nature of AII-induced effects}

What determines the relative expression of the two types of calcium current responses? The nodose ganglion is itself a het-

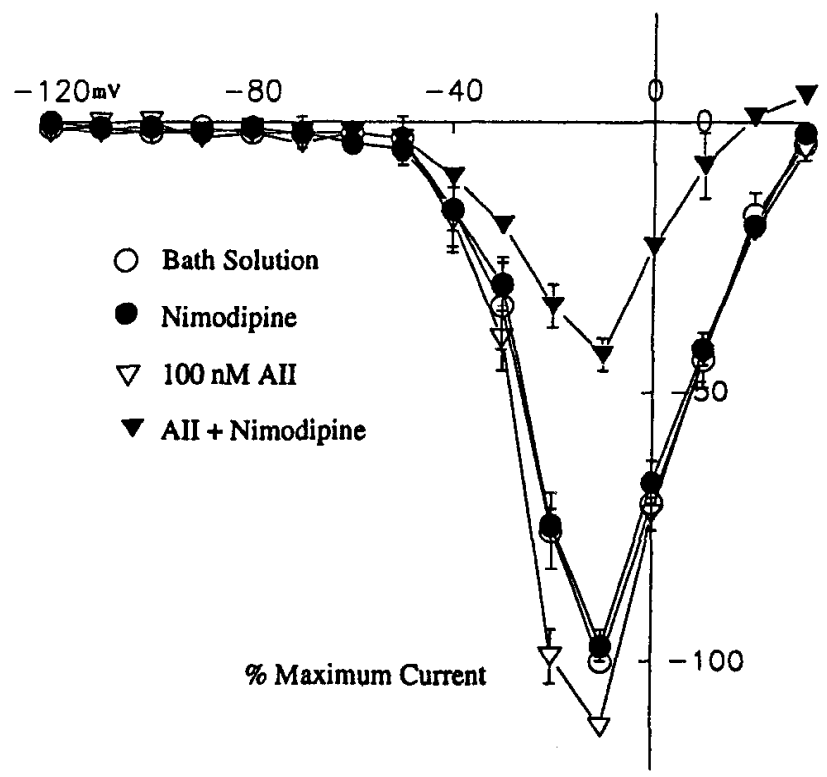

Figure 15. Dual effects of AII. Perfusion with $2 \mu \mathrm{M}$ nimodipine alone had no effect on whole-cell calcium current, while a small change in calcium current was seen upon perfusion with AII alone. Subsequent perfusion of AII and nimodipine together, however, eliminated a facilitation and caused a reduction in calcium current $(n=4)$. 
erogeneous structure representing many different sensory modalities. Cell-to-cell variation was therefore anticipated, but, surprisingly, the variation was between cells prepared from different litters and not among cells of the same litter. One possibility to account for the presence of the facilitory versus inhibitory response was a difference in the relative cxpression of calcium channel types. For instance, cells without a reserve pool of DHP-sensitive channels would not show a facilitation of calcium current. Experiments using Bay K 8644 to activate DHP-sensitive channels indicated that these channels were present even in cells which exhibited no facilitation. Furthermore, CTX-sensitive channels, substrate for the inhibitory effect, were always present. The variation is therefore more likely due to changes in expression of types of AII receptors or in the systems that couple the receptors to ion channels. Changes in the expression of AII receptors with development have been reported (Tsutsumi and Saavedra, 1991). Since the data presented in this report were obtained from neonatal animals, a comparison with the responses of fetal and adult nodose neurons may provide an answer to the question of differential expression.

\section{Functional role of AII receptors in the NTS}

Casto and Phillips (1986) and Kubo and Kihara (1990) reported that microinjection into the NTS of high concentrations of AII (>100 ng) causes an increase in blood pressure, while application of lower concentrations leads to depressor effects. The resultant U-shaped dose-response curve may be due to the dual effects of AII reported in the present study. In a preliminary report a single concentration of AII was shown to incrcase the amplitude of the excitatory postsynaptic potential of NTS neurons responding to stimulation of the afferent tract containing the nodose axons. The postsynaptic neuron was unaffected (Yang and Andresen, 1991). This suggests that AII receptors are located at the presynaptic terminal although it does not indicate which of the AII receptor subtype(s) is present.

In summary, the data presented here indicate AII-induced inhibition and facilitation are mediated through different receptors, different cellular pathways, and different ion channels. The inhibitory effect involves $\mathrm{AT}_{1}$ receptors, PTX-sensitive G-proteins, and CTX-sensitive calcium channels, while the facilitation utilizes non-AT, receptors, a PTX-insensitive coupling system, and a reserve pool of DHP-sensitive channels.

\section{References}

Allen AM, Lewis SJ, Verberne AJM, Mendelsohn FAO (1988) Angiotensin receptors and the vagal system. Clin Exp Hypertens [Theory Pract] A10:1239-1249.

Allen IS, Cohen NM, Dhallan RS, Gaa ST, Lederer WJ, Rogers TB (1988) Angiotensin II increases spontaneous contractile frequency and stimulates calcium current in cultured neonatal rat heart myocytes: insights into the underlying biochemical mechanisms. Circ Res 62:524-534.

Artalejo CR, Ariano MA, Perlman RL, Fox AP (1990) Activation of facilitation of calcium channels in chromaffin cells. Nature 348:239242.

Bacal K, Kunze DL (1993) Angiotensin II reversibly reduces calcium currents in neonatal rat nodose neurons. FASEB J 7:A94.

Bacal K, Priddy MA, Kunze DL (1991) Angiotensin II reversibly increases calcium currents in cultured rat nodose neurons. Physiologist 34:242.

Bonvallet R, Rougier O (1990) Existence of two calcium currents recorded at normal calcium concentrations in single frog atrial cells. Cell Calcium 10:499-508.

Casto K, Phillips MI (1986) Neuropeptide action in NTS: angiotensin specificity and hypertensive rats. Am J Physiol 249:R341-R347.
Chaki S, Inagami T (1992) A newly found angiotensin II receptor subtype mediates cyclic GMP formation in differentiated Neuro-2A cells. Eur J Pharmacol 225:355-356.

Cohen CJ, McCarthy RT, Barrett PQ, Rasmussen H (1988) Ca channels in adrenal glomerulosa cells $\mathrm{K}$ and angiotensin II increase T-type Ca channel current. Proc Natl Acad Sci USA 85:2412-2416.

Cox DH, Dunlap K (1992) Pharmacological discrimination of N-type from L-type calcium current and its selective modulation by transmitters. J Neurosci 12:906-914.

Crain SM, Shen KF (1990) Opioids can evoke direct receptor-mediated excitatory effects in sensory neurons. Trends Pharmacol Sci 11: 77-81.

Diz DI, Barnes KL, Ferrario CM (1986) Contribution of the vagus nerve to AII binding sites in the canine medulla. Brain Res Bull 17: 497-505.

Dolphin AC, Scott RH (1989) Modulation of calcium currents in sensory neurons by pertussis toxin-sensitive G-proteins. Ann NY Acad Sci 560:387-390.

Fuxe K, Bunnemann B, Aronsson M, Tinner B, Cintra A, von Euler G, Agnati LF, Nakanishi S, Ohkubo H, Ganten D (1988) Pre- and postsynaptic features of the central angiotensin systems: indications for a role of angiotensin peptides in volume transmission and for interactions with central monoamine neurons. Clin Exp Hypertens [Theory Pract] A10:143-168.

Gutkind JS, Kurihara M, Castren E, Saavedra JM (1988) Increased concentration of angiotensin II binding sites in selected brain areas of spontaneously hypertensive rats. J Hypertens 6:79-84.

Healy DP, Rettig R, Nguyen T, Printz MP (1989) Quantitative autoradiography of angiotensin II receptors in the rat solitary-vagal area: effects of nodose ganglionectomy or sinoaortic denervation. Brain Res 484:1-12.

Hescheler J, Rosenthal W, Trautwein W, Schultz G (1987) The GTPbinding protein $G_{o}$ regulates neuronal calcium channels. Nature 325 : 445-447.

Inagami T, Harris RC (1993) Molecular insights into angiotensin II receptor subtypes. News Pharmacol Sci 8:215-218.

Iredale PA, Martin KF, Hill SJ, Kendall DA (1992) Agonist induced changes in intracellular calcium concentration in N1E-115 cells: differential effects of bradykinin and carbachol. Eur J Pharmacol 226: 163-168.

Kubo T, Kihara M (1990) Modulation of the aortic baroreceptor reflex by neuropeptide $\mathrm{Y}$, neurotensin, and vasopressin microinjected into the NTS of the rat. Naunyn Schmiedebergs Arch Pharmacol 342:182188

Lind RW, Swanson LW, Ganten D (1985) Organization of AII immunoreactive cells and fibers in the rat central nervous system. Neuroendocrinology 40:2-24.

McMillian MK, Tuominen RK, Hudson PM, Suh HH, Hong JS (1992) Angiotensin II receptors are coupled to $\omega$-conotoxin-sensitive calcium influx in bovine adrenal medullary chromaffin cells. J Neurochem 58: 1285-1291.

Mendelowitz D, Kunze DL (1992) Characterization of calcium currents in aortic baroreceptor neurons. J Neurophysiol 68:509-517.

Mogul DJ, Adams ME, Fox AP (1993) Differential activation of adenosine receptors decreases $\mathrm{N}$-type but potentiates $\mathrm{P}$-type $\mathrm{Ca}^{2}+$ current in hippocampal CA3 neurons. Neuron 10:327-334.

Pinzani M, Failli P, Ruocco C, Casini A, Milani S, Baldi E, Giotti A, Gentilini $P$ (1992) Fat storing cells as liver-specific pericytes. Spatial dynamics of agonist-stimulated intracellular calcium transients. J Clin Invest 90:642-646.

Saito F, Hori MT, Ideguchi Y, Berger M, Golub M, Stern N, Tuck ML (1992) 12-Lipoxygenase products modulate calcium signals in vascular smooth muscle cells. Hypertension 20:138-143.

Speth RC, Dinh TT, Ritter S (1987) Nodose ganglionectomy reduces AII receptor binding in the rat brainstem. Peptides 8:677-685.

Timmermans PBWM, Wong PC, Chui AT, Herblin WF, Benfield P, Carini DJ, Lee RJ, Wexler RR, Saye JM, Smith RD (1993) Angiotensin II receptors and angiotensin II receptor antagonists. Pharmacol Rev 45:205-251.

Tremblay E, Payet MD, Gallo-Payet X (1992) Effects of ACTH and angiotensin II on cytosolic calcium in cultured adrenal glomerulosa cells. Role of cAMP production in the ACTH effect. Cell Calcium $12: 655-673$.

Tsutsumi K, Saavedra JM (1991) Characterization and development of type 1 and type 2 angiotensin II in rat brain. Am J Physiol 261: R209-R216. 
Wiley JW, Gross RA, Lu Y, MacDonald RL (1990) Neuropeptide Y reduces calcium current and inhibits acetylcholine release in nodose neurons via a pertussis toxin sensitive mechanism. J Neurophysiol 63:1499-1507.

Yang M, Andresen MC (1991) Angiotensin enhances sensory afferent synaptic transmission in neurons of rat medial nucleus tractus solitarius. FASEB J 5:A677.

Yawo H, Chuhma N (1993) Preferential inhibition of $\omega$-conotoxin sensitive presynaptic $\mathrm{Ca}^{2+}$ channels by adenosine autoreceptors. Nature 365:256-258. 